\title{
Features and prospects of using collagenase-containing enzyme compositions in the meat-based products technology
}

\section{Dmytro Garmash, Vasyl Pasichnyi}

\section{National University of Food Technologies, Kyiv, Ukraine}

\section{Keywords:}

Meat

Fermentation

Collagenase

Enzyme

Composition

Article history:

Received

17.10.2017

Received in revised

form 29.11.2017

Accepted 29.12.2017

\section{Corresponding author:}

Vasyl Pasichnyi

E-mail:

pasww1@ukr.net

DOI:

$10.24263 / 2310-$

$1008-2017-5-2-7$

\section{Abstract}

Introduction. The research problem of synergistic effects that can be observed on parallel or sequential fermentation of meat and vegetable raw materials is not widely presented and requires a more detailed consideration of these issues.

Materials an methods. The object of research is the technology of meat-based products. Substance - low-grade fermentation. The methods of analysis and synthesis were used, literature sources, presented by publications of leading scientists, whose works are devoted to processes of fermentation of animal and plant raw materials and synergistic effects in these processes, are considered.

Results and discussion. The possibility of simultaneous hydrolysis of proteins of the main meat raw material makes it possible to modify the biological value of the product within wide limits. Barely only of the limiting factors here are the biological activities of individual amino acids. All amino acids are biologically active substances and excessive amount of them in the free state in an unbalanced ratio with others can have a negative effect. This question is more relevant to the medical and biological, but should be taken into account when evaluating and modeling the composition and fermentation of new meat-containing products. The fermentation regimes of raw materials can vary in time and space. In many cases, it is rational to use certain processes for the fermentation of plant and meat raw materials in order to avoid excessive microbiological insemination and overlay effects of different groups of enzymes. This issue is to be dealt with separately for each particular formulation and enzyme combination, but in many cases it is more appropriate to separate the fermentation of meat and vegetable raw materials with the further inactivation of enzymes at high temperatures and the addition of minced meat with inactivated enzymes. Synergistic effects between different types of proteolytic enzymes are studied mainly for meat products. The course of fermentation processes under influence simultaneously on meat and vegetable raw materials is poorly investigated. As has been said above, in many cases, such studies are not feasible due to the effectiveness of separating fermentation of meat and vegetable raw materials, however, in many cases, these synergistic effects should be explored.

Conclusions. The processes of fermentation and proteolysis in the meat raw material can be carried out with the use of a number of enzymes of both natural and synthetic origin. Fermentation of plant material can be carried out in parallel (simultaneously) or separated in time and space with enzymatic treatment of meat raw materials. 


\section{Introduction}

The world market of meat products is in an unstable state in recent years. This is due to an increase in demand and total consumption in one group of countries and to a decrease in the other. It should be noted that the global level of world consumption of meat products is increasing, given the growing population and economic development of Africa and Asia [1]. However, it is worth analyzing the trends in the qualitative composition of meat products. WHO official publications, according to which meat products from the "red" (beef, pork) meat are classified as "potentially carcinogenic" products affecting a large number of consumers in the countries of Europe and North America [1,2]. Current research shows that there are certain chemicals in red and processed meats - both added and naturally occurring - that cause these foods to be carcinogenic. For example, when a chemical in red meat called haem is broken down in the gut, N-nitroso chemicals are formed and these have been found to damage the cells that line the bowel, which can lead to bowel cancer. These same chemicals also form when processed meat is digested. In addition, the nitrite and nitrate preservatives used to preserve processed meat produce these $\mathrm{N}$-nitroso chemicals and can lead to bowel cancer. Therefore, it is highly probable that this trend will take place in the domestic market. Analyzing the reasons for changing the structure of the domestic meat market, it is worth pointing out as the main factors a sharp increase in prices for pork, beef and poultry meat. The causes of these phenomena - the epidemiological pattern of disease of pigs and poultry market monopolization $[3,4]$.

Taking into account the given trends, development and improvement of technologies of meat-based products will solve several problems of the market and industry at once. First, it will reduce the cost of production by reducing the share of the most valuable raw materials (veal beef, pork and lamb of the highest and first grades). Secondly, it will expand the range of products, which will positively affect the development of the market and industry. Third, increase the rationality of processing low-grade meat raw materials, by combining it with plant raw materials rich in protein $[5,6]$.

However, this direction of technology requires improvement. When developing new and application of known technologies for the production of meat-based products, some disadvantages are becoming apparent. The first drawback is the complexity of supply and primary processing of plant raw materials. This raw material has a high moisture content, which negatively affects the shelf life and structure of the product when it is introduced without proper treatment. Ways of solving this problem - application of extruders, drying of raw materials with pre-shredding, lyophil drying, heat treatment under specific conditions [7]. The second disadvantage is the low biological value of plant material. As a result, the restriction of the use of low-grade meat raw materials due to the general value of the product.

To address these issues, it is advisable to use targeted fermentation. Fermentation can increase the biological value of low-grade raw meat and plant material generally by acting on peptide bonds in proteins and monomerizatsiyi amino acids and peptides. As a result, due to the formation of free amino acids and peptides, the content of all essential amino acids in the product is achieved. According to Mitchell's law, this will lead to an increase in the absorption of other amino acids that contain large amounts of plant and collagencontaining raw materials [8].

The use of collagenase in the technology of meat-based products has advantages not only in increasing the biological value of the product, but also increases the technological characteristics (positively affects the structure, rheological characteristics and homogeneity of the forage system) product [9]. However, the created kind of apple systems requires the 
use of enzymes for the processing of plant raw materials. Also, it is worth considering other types of enzymes that may exhibit positive (or synergistic) effects when making meaty products in the formulation in combination with collagenase. Among several enzymes should be identified such as fitsyn, papain and bromelin.

These enzymes belong to the class of proteases (proteolytic enzymes) and act on peptide bonds between amino acids in proteins, channeling their hydrolysis. Ficcin, papain and bromelin have isoelectric points, which are achieved at high ( 8 and higher) $\mathrm{pH}$ values. Therefore, suitable for use in the meat industry.

\section{Material and methods}

The object of research is the technology of meat-based products. Substance - lowgrade fermentation.

During the writing of the article the methods of analysis and synthesis were used, literature sources, presented by publications of leading scientists, whose works are devoted to processes of fermentation of animal and plant raw materials and synergistic effects in these processes, are considered.

\section{Results and discussion}

The aim of the work was to consider the relevance, prospects and peculiarities of the technology of meat products with the use of fermentation, analyze the publications on the chosen topic and draw a conclusion on the prospects of combining collagenase with other enzymes in meat-based products technology, to consider the available types of enzymes and their application technologies on the market, to identify the disadvantages of the technological process of meat products production and the prospects for their elimination.

In general consumer perception towards the intake of meat and meat products is unhealthy because it may increase the risk of diseases like cardiovascular diseases, obesity and cancer, because of its high fat content (especially saturated fat) and added synthetic antioxidants and antimicrobials. Addition of plant derivatives having antioxidant components including vitamins $\mathrm{A}, \mathrm{C}$ and $\mathrm{E}$, minerals, polyphenols, flavanoids and terpenoids in meat products may decrease the risk of several degenerative diseases. To change consumer attitudes towards meat consumption, the meat industry is undergoing major transformations by addition of nonmeat ingredients as animal fat replacers, natural antioxidants and antimicrobials, preferably derived from plant sources.

Fitsin belongs to the group of papainases. According to Liner, it contains in its molecule at least two sulfhydryl groups, of which only one is in the catalytic region of the enzyme. In addition, ficin contains one disulphide group that is not essential for its activity. By its action on ficin proteins, pepsin resembles that, since its protein splitting catalyzes proteins to the stage of polypeptides that have an amine nitrogen ratio of up to $25 \%$ overall. In the technology of meat products, ficin is used to soften the main raw material along with papain and bromelin (bromelain).

The research has found that the introduction of the enzyme complex on the basis of ficin, pineapple and papaya processing products increases the overall efficiency of the process and reduces the strength of the raw material for compression from $17.45 \mathrm{kPa}$ (for the use of mono-enzyme mixtures) to $16.45 \mathrm{kPa}$ (for a combination of enzymes) [10]. 
Papain - a plant enzyme derived from the fruits of the evergreen tropical papaya tree. In addition, the pulp of papaya fruit itself is tasty, which makes these fruits every year more and more popular in our country, it contains milk juice, rich in many useful substances and trace elements. To get juice you need to use only immature fruits. It appears after a cut of the skin of the fetus. But this is not the only way to get a papain - in addition to natural origin, the enzyme is also produced by the chemical synthesis of papain.

An important alternative to papaya and ficin in meat products is fungal and bacterial proteases. Studies of a team of scientists from New Zealand have compared the effects of different protease types on the characteristics of protein of meat raw material (first class beef and extracts of the tendons of cattle and pigs) [11]. The authors conclude that such optimal regimes for the hydrolysis of the investigated raw material, in which there is a significant synergistic interaction of papain-collagenase $-45^{\circ} \mathrm{C}, \mathrm{pH}$ ranges from 5.2 to 7.5. From this we can draw conclusions about the effectiveness of the joint application of these enzymes in meat products technology, as these regimes are fully implemented during the initial processing of raw materials.

In the work of the team of scientists on the influence of papain and collagenase on the fascia and intramuscular connective tissue, it was established that the introduction of this combination allows the release of insoluble collagen in the intercellular plasma, which greatly affects the structure of the final product [12].

Microbial collagenases are important and promising enzymes, taking into account the industrial and biological perspectives for their application. Recent work on their potential use in the food industry and the benefits of health effects have shown that microbial collagenase has significant prospects as a major component for biologically active functional ingredients and for peptides. Collagenases are important virulence factors that play a decisive role in the global degradation of extracellular animal protein matrices due to their ability to split collagen. There is no scientific consensus on the well-defined and proper screening of collagenase produced by micro-organisms. A lot of discussions can be found in the literature on the correct identification of microbial collagenase. Modern technologies and strategies used to improve the screening, production and purification of microbial collagenase with full detail, especially with regard to the classification, structures and mechanisms of collagen-cleavage of the representatives of collagenases of the M9 family. The potential of microbial collagenase in the development of a process of softening meat and bioactive "true" collagen peptides or obtaining hydrolyzates. In addition, critical issues and different strategies for potential uses of collagenase in the food, food, biotechnology and medical sectors are underlined. [13].

To study the effect of enzymes on monomerization of plant proteins, it is important to understand the process of decomposition of homologagacturonan (HG) (the most common pectin polymer) by specific enzymes. HG, a polymer that can be methylated or acetylated. Both the degree of substitution (methylation and / or acetylation) and polymerization can be controlled by specific enzymes such as pectin methyl esterase (PME), pectin acetyl esterase (PAE), polygalacturonase (PG), or pectinal lysis (PLA). Over the past 10 years had been achieved in the biochemical and functional description of these enzymes [14].

In the work of the team of scientists from the United States conducted comparative studies of the impact of two types of microbiological enzymes on the monomerization of protein and carbohydrate soybeans simultaneously [15]. Soy protein is a valuable nutritional supplement for animal feed. While the protein is $\sim 50 \%$ skimmed soy flour, it coexists with complex carbohydrates (30-35\%), which may have a negative effect on the nutritional value. The enzymatic process can remove carbohydrates and produce a proteinrich soy product. Hydrolyzate with monomerised carbohydrates is a valuable enzyme raw 
material. In this study, the enzymes of the micro-organisms of the species Aspergillus niger and Trichoderma reesei were compared with respect to the use in the hydrolysis of carbohydrates. To determine the enzymatic conversion, the following conditions were applied: $\mathrm{pH} 3.2-6.4$, temperature $\left(40-60^{\circ} \mathrm{C}\right)$. The effects of factors and interaction between them are investigated. The optimal $\mathrm{pH}$ and temperature were virtually identical for both enzymes: $\mathrm{pH} 4.8$ and $50-51{ }^{\circ} \mathrm{C}$ for the first strain and $\mathrm{pH} 5.1-5.2$ and $48-51{ }^{\circ} \mathrm{C}$ for the second one. Both enzymes also provide similar protein content in soy protein concentrates, ie $74-75 \%$ versus the indicator of $64-68 \%$ for most concentrates in the market. The A. niger enzyme was significantly more effective in converting carbohydrates, reaching efficiency up to $75 \%$.

The feasibility of concurrent monomerization of proteins and carbohydrates is not always justified. The reason for this is the ability of monosaccharides to shift the $\mathrm{pH}$ of the environment and influence the autolytic processes in the main raw materials of meat products. Also, the lack of the presence of monosaccharides is the acceleration of the development of undesirable microflora due to the presence of nutrient medium for microorganisms. It is worth noting the deterioration of organoleptic properties - the taste of the finished product.

According to the given literary sources - results of researches and publications on the chosen theme, it is possible to make a number of conclusions about the current state and problems in the technology of meat-based products and the application of enzyme combinations in this direction.

The possibility of simultaneous hydrolysis of proteins of the main meat raw material makes it possible to modify the biological value of the product within wide limits. The limiting factor here is the biological activity of individual amino acids. All amino acids are biologically active substances and excessive amount of them in the free state in an unbalanced ratio with others can have a negative effect. This question relates more to the biomedical, but should be taken into account when evaluating and modeling the composition and fermentation of new meat-based products.

It should be remembered that the fermentation of raw mode can be varied in time and space. In many cases, it is rational to use certain processes for the fermentation of plant and meat raw materials in order to avoid excessive microbiological insemination and overlay effects of various groups of enzymes - those used for monomerization and responsible for the polymerization of carbohydrates. This issue is to be dealt with separately for each specific formulation and enzyme combination, but in many cases it is more appropriate to separate the fermentation of meat and plant raw materials with the further inactivation of enzymes at high temperatures and the addition of minced meat with inactivated enzymes.

The expediency of using collagenase in combination with other enzymes is appropriate in the vast majority of cases when using low-grade meat raw materials. Factors limiting the use of this enzyme are primarily economical - in many cases it is impractical to use collagenase for the hydrolysis of raw materials if the proportion of such raw material in the formulation is too small. Or the opposite - it is inappropriate to introduce additional enzymes if the basis of the formulation is only collagen-containing raw materials.

Synergistic effects between different types of proteolytic enzymes are studied mainly for meat products. The course of the fermentation process when subjected to both meat and plant material is less explored. As has been said above, in many cases, such studies are not feasible due to the effectiveness of separating fermentation of meat and plant raw materials, however, in many cases, these synergistic effects should be explored [16, 17].

Bioactive peptides are short amino acid sequences, that upon release from the parent protein may play different physiological roles, including antioxidant, antihypertensive, 
antimicrobial, and other bioactivities. They have been identified from a range of foods, including those of animal origin, e.g., milk and muscle sources (with pork, beef, or chicken and various species of fish and marine organism). Bioactive peptides are encrypted within the sequence of the parent protein molecule and latent until released and activated by enzymatic proteolysis, e.g. during gastrointestinal digestion or food processing. Bioactive peptides derived from food sources have the potential for incorporation into functional foods and nutraceuticals. The aim of fermentation process in technology of meat-based products is also to rise the intake of muscle-derived bioactive peptides, especially those of fermented meats and the potential benefits of these bioactive compounds to human health $[18,19]$.

Ability to use bacterial and other enzymes of microbiological origin is closely related to the type of a specific producer organism, and therefore requires further research. The given publications show high enzyme activity of enzymes of microbiological origin, but there are some restrictions in their application which can have both economic and logistic character [20]. These issues require further consideration and concretization for domestic conditions.

\section{Conclusions}

According to the analysis of publications, the results of leading research, market trends and WHO recommendations, the production of meat-based products is feasible and promising given several factors.

The first factor is the lack of research data, which are aimed to meat and plant fermentation process during the processing of meat-based products. Many scientific articles are aimed to meat and collagen-containing stuff fermentation that is caused by high biological value of these types of stuff. But also fermentation of the plant and vegetable stuff wasn 't considered in equial level and need to be estimated better.

The second factor is the possibility of simplifying the technological process of processing plant and collagen-containing raw materials with increasing its full value.

The use of enzyme compositions comprising collagenase is effective in view of the synergistic effects that have been proven by the experimental method for meat raw material. Synergistic effects and qualitative composition of enzyme compositions in their interaction in the meat-stuff minced meat system require further research, but even for negative results, it is possible to solve the problem by the method of separate fermentation of meat and plant raw materials.

Among the types of enzymes, it is worth highlighting the most effective enzymes that have the maximum effect on the meat raw material. According to the analyzed publications, it is worth allocating ficin, bromelin, papain and proteases of microbiological origin. According to the results of studies, these enzymes exhibit high activity separately and do not reduce it in absolute majority of cases and with a consistent application, have an isoelectric point, optimal temperatures and $\mathrm{pH}$ levels that are easy to provide in the meat processing industry. it can be concluded that further research is needed on the processes of fermentation of meat and plant raw materials and the synergistic effects between enzymes in these systems. 


\section{References}

1. Stoll-kleemann S., Schmidt U. J. (2017), Reducing meat consumption in developed and transition countries to counter climate change and biodiversity loss: a review of influence factors. Regional Environmental Change, 2017, 17(5), pp. 1261-1277.

2. Mcguire Shelley (2015), World cancer report 2014. Geneva, Switzerland: World Health Organization, international agency for research on cancer, WHO Press, 2, pp. $2-15$.

3. Tashmatov V.A. (2017), Epizootiia, yak odna z pidstav vvedennia nadzvychainoho stanu $v$ Ukraini. Orhanizatsiia profesiinoi pidhotovky $v$ pidrozdilakh Natsionalnoi politsii Ukrainy: materialy kruhloho stolu, ODUVS, Odesa.

4. Todosiichuk V. L. (2017), Stan ta problemy prodovolchoi bezpeky v Ukraini. Ekonomika. Finansy. Menedzhment: aktualni pytannia nauky i praktyky, 2017, 3, pp. 142-150.

5. Pasichnyi, V. M. (2002), Ranhove otsiniuvannia kombinovanykh miasoproduktiv, Naukovi pratsi NUHT, 11, pp. 77-80

6. Pasichnyi V. M., Strashynskyi I.M., Fursik O.P. (2015), Doslidzhennia emulsii na osnovi bilokvmisnykh funktsionalnykh kharchovykh kompozytsii, Tekhnolohycheskyi audyt y rezervy proyzvodstva, 3(3), pp. 51-55.

7. Pasichnyi V.M., Yastreba Y.O. (2010), Vyznachennia optymalnykh umov pryhotuvannia poroshkopobidnoho napivfabrykatu z hrybiv hlyva zvychaina za mikrobiolohichnymy pokaznykamy, Obladnannia ta tekhnolohii kharchovykh vyrobnytstv, 1, pp. 8-11.

8. Perini Matteo, et al. (2013), Effect of origin, breeding and processing conditions on the isotope ratios of bioelements in dry-cured ham6 Food chemistry, 136(3-4), pp. 15431550 .

9. Bekhit Alaa A., et al. (2014), Exogenous proteases for meat tenderizationб Critical reviews in food science and nutrition, 54(8), pp. 1012-1031.

10. Manea Iuliana, Manea Laur, Marinescu Valeria (2016), study concerning the proteolytic activity of vegetable enzymes on cured meat quality, Annals. Food Science and Technology, 17(2), pp. 421-425.

11. Minh Ha, et al. (2013), Comparison of the proteolytic activities of new commercially available bacterial and fungal proteases toward meat proteins, Journal of food science, $78(2)$, pp. 14-22.

12. Purslow P. (2014), New developments on the role of intramuscular connective tissue in meat toughness, Annual review of food science and technology, 5, pp. 133-153.

13. Pal Gaurav Kumar, Suresh P.V. (2016), Microbial collagenases: challenges and prospects in production and potential applications in food and nutrition, RSC Advances 6(40), pp. 33763-33780.

14. Sénéchal Fabien, et al (2014), Homogalacturonan-modifying enzymes: structure, expression, and roles in plants, Journal of experimental botany, 65(18), pp. 51255160

15. Loman Abdullah A.; Lu-Kwang J.U. Optimization of enzymatic process condition for protein enrichment, sugar recovery and digestibility improvement of soy flour, Journal of the American Oil Chemists' Society, 93(8), pp. 1063-1073.

16. Lu S., Ji H., Wang Q., Li B., Li K., Xu C., Jiang C. (2015). The effects of starter cultures and plant extracts on the biogenic amine accumulation in traditional Chinese smoked horsemeat sausages, Food Control, 50, pp. 869-875. 


\section{— Food Technologies}

17. Ukrainets A., Pasichnyi V., Shvedyuk D., Matsuk, Y. (2017). Investigation of proteolysis ability of functional destinated minced half-finished meat products, Scientific Messenger of LNU of Veterinary Medicine and Biotechnologies, 19(75), pp. 129-133.

18. Pasichnyi V., Ukrainets A., Shvedyuk D., Al-Hashimi H.M., Matsuk Y. (2017). Determination of the Optimal Sterilization Regime of Canned Quail Meat with Hydrocoloids Application, EUREKA: Life Sciences, (4), pp. 21-25.

19. Bartkiene E., Mozuriene E., Juodeikiene G., Zadeike D., Maruska A., Stankevicius M., Cizeikiene D. (2015), Pork meat products functional value and safety parameters improving by using lactic acid fermentation of savory plants, Journal of Food Science and Technology, 52(11), pp. 7143-7152.

20. Hur S. J., Lee S. Y., Kim Y. C., Choi I., Kim G. B. (2014), Effect of fermentation on the antioxidant activity in plant-based foods, Food chemistry, 160, pp. 346-356. 